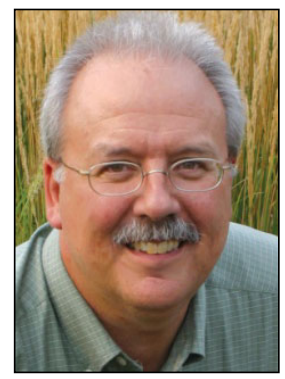

\author{
Metrics fROM THE FIELD \\ Blending insights from research with insights from practice \\ Ken Meter
}

\title{
Building a framework for sustainable livelihoods
}

Published online 6 December 2012

Citation: Meter, K. (2012). Building a framework for sustainable livelihoods. Journal of Agriculture, Food Systems, and Community Development, 3(1), 13-15. http://dx.doi.org/10.5304/jafscd.2012.031.009

Copyright (C) 2012 by New Leaf Associates, Inc.

L ocal food networks in North America operate in relatively wealthy societies, yet they hold many concerns that are shared by communities in places such as those featured in this issue of the Journal of Agriculture, Food Systems, and Community Development. What could we learn from each other?

When I studied the food systems of Ohio and Indiana, I found that those who were most adept at transforming these food systems had common formative experiences: they had worked for a significant block of time in a so-called "developing" nation. At core, these leaders emphasized patience and inclusive processes. They understood that they were working outside the mainstream

Ken Meter, president of Crossroads Resource Center, has taught economics at the University of Minnesota and the Harvard Kennedy School. He is one of the most experienced food system analysts in the U.S., having produced 85 regional and state food system assessments in 30 states, focused on geographic farm and food economies. A member of the Alliance for Building Capacity, he is also the author of Hoosier Farmer? Emerging Food Systems in Indiana. paradigm and could not count on significant support to achieve long-term visions. Having worked in settings where resources were limited, they knew how to make significant progress while spending little.

Any region of the globe that strives to feed itself struggles with the same pressures. Each accomplishes great feats simply to survive amidst a political and economic climate that is dedicated to extracting resources from their communities. Each strives for more diverse options than an exportfocused, commodity approach to agriculture, and each works to transcend a monocultural vision of life. Each asserts that local resources should be devoted to feeding local people first. Each works consciously to build social connectivity, and often has done so for decades.

Moreover, in both developing and developed settings, local food leaders are currently being criticized by foundations and investors. The complaint runs something like this: "We've been pouring money into your work for years, but we don't see enough tangible return for our investment. Why aren't you making a bigger impact?" 
It may seem odd that those who have great wealth criticize those who have far less. After generations of having their best resources including their youth — sucked away, marginalized areas are somehow being asked to hold themselves responsible for creating a significant return on investment for those who benefited as wealth was extracted.

This is not to point fingers at individual investors or funders: the issues we wrestle with are structural, and often so integral to our way of life that they are completely invisible to those of us who are privileged. Yet they are far from invisible to those of us who suffer the consequences. Without recognizing these extractive structures for what they are, there is little hope for building frameworks that allow sustainable livelihoods to be created.

That is to say, of course, that we will have limited success in building sustainable livelihoods - our victories must necessarily be small and scattered - until society builds supportive economic and policy infrastructure. The good news is that all of the infrastructure we have built was deeply shaped by public policy, so it can be changed. The bad news is that these structures hold such power that changing them will take time. This is one reason that people with experience in the developing world work at the margins, since it is in this space that people find more freedom to invent.

More good news: Nations such as France, Italy, Norway, Sweden, Austria, Brazil, Tanzania, and Japan (to name only selected cases) have fashioned economic structures that build capacity and wealth at the local level. In large part this was because each correctly perceived it would have little economic clout in a world dominated by superpowers unless it built mechanisms that would strengthen its own capacity. Yet the U.S. has steadfastly refused to learn from these global partners.

Below are some concepts that guide my own work.

1. Local foods work has been brewing for generations. We do seem to be in the middle of one of the great periods of emergence for interest in community-based foods, but history also offers us a wealth of prior experience to draw upon. It is interesting to watch investors who suddenly discover the potential for local foods demand a quick return from seasoned practitioners who have worked for little return for decades - often creating, without reward, the very momentum that allows investors to take an interest.

\section{The current crisis is one of capital accumu-} lation. When capital is accumulated by a few at the expense of the many, massive disparities are created, and the economy stagnates. Yet U.S. policies subsidize further accumulation of capital, as if this were universally a good. Similarly, developing nations often count accumulation of wealth by the elite as "progress."

\section{Worldviews are far more important than} money in shaping future outcomes. Rapid change is forcing us to rethink our dearest habits and our assumptions of privilege. If we think differently, money may flow differently.

4. Ultimately, infrastructure is the key. If we build economic structures that support community wealth creation, we will find communities creating wealth. The savings and loan industry is an excellent example from U.S. history. This is a banking system that was created to foster the hope that lower- and middle-income households could build savings accounts and buy homes. When it was dismantled, the concept of savings itself eroded. Similarly in Africa, as Timberlake (1986) showed, foreign aid essentially created structures that fostered greater dependency.

5. Scale is both the problem and the solution. Many of the extractive features of the prevailing economy are due to large-scale institutions and business networks. Simply attaching to these structures will not create a solution that builds local capacity. Simply emulating them will re-create the very problems we set out to solve. We certainly need to aggregate, but the 
appropriate scale may be far lower than we now imagine (Meter, 2004). Moreover, if scale is built too quickly, or in a top-down manner, little capacity will be built in disadvantaged communities. One participant in a recent Springfield, Illinois, forum on food and health issues re-framed this quite eloquently: "How do we scale up connectivity?"

What ultimately connects food practitioners in the developing world with those in North America is a common understanding of being marginalized. The key difference, it seems to me, for those of us in the developed world is that we have both benefited from extractive economies, and also fallen victim to them. This makes it more difficult for us to see these dynamics clearly. Yet we all have much to gain by breaking the shackles of dependency, for even those who seem to benefit ultimately lose. It seems likely that the richest lessons will emerge from the "Third World" - whether in developing nations, or inside the U.S.

\section{References}

Meter, K. (2004). Economies of size considerations for Hiawatha Fund. Crossroads Resource Center and the University of Minnesota Experiment in Rural Cooperation. Available at Crossroads Resource Center website: http://www.crcworks.org/size.pdf

Timberlake, L. (1986). Africa in crisis: The causes, the cures of environmental bankruptcy. Philadelphia: New Society Publishers. 